\title{
SOCIO-CULTURAL ENVIRONMENT OF CHANGPA NOMADS OF CHANGTHANG REGION (LADAKH)
}

\section{TASHI DOLKAR ${ }^{1} \&$ HUMMARA AZIM ${ }^{2}$}

${ }^{1}$ Research Scholar, home science department University of Kashmir, Jammu and Kashmir, India

${ }^{2}$ Assistant Professor Institute at Home Science, University of Kashmir, India

\begin{abstract}
The present study was aimed at people of Changthang, known as Changpa or Drukpa, who are nomadic shepherds. Majority of the Changpa nomads lived in rebo (tents) made from yak wool and their lives were centered around their livestock. They roam from one pastureland to another, trading meat, wool and unprocessed cashmere. Data also revealed that $100 \%$ of the women respondents were celebrating losar festival. Losar festival marks the beginning of New Year in ladakh. All the Changthangi women wear ladakhi traditional dress Gonchas. Majority of the respondents prayer occasionally.
\end{abstract}

KEYWORDS: Changpa, Nomads, Women \& Households

Received:Jul 10, 2017; Accepted:Jul 25, 2017; Published: Jul 29, 2017; Paper Id.: IJASRAUG201763

\section{INTRODUCTION}

The present study deals with the Changpas of Changthang, Ladakh in India. Ladakh is a cold desert. Changthang (Chang- north, thang- plain) literally means the "north plain" The region is geographically situated in the eastern part of Ladakh, the easternmost part of the state of Jammu and Kashmir northern India. It is the land of nomads located in the east of Leh on the Chinese border. In Changthang, winters are cold and Arctic-like, despite the latitude, due to the high elevation and very harsh winter with temperatures falling to $-35^{\circ} \mathrm{C}$ associated with heavy snowfalls and bitter winds. During the brief summer, temperatures are high in the day, but fall to around $0^{\circ} \mathrm{C}$ at night. The remoteness and relatively low productivity due to low temperatures and dry climate have left it relatively little exploited. (Pascale Dollfus 2013). The culture of changthangi people is an interesting mix of Tibetan and other customs. The Changpa are Buddhists and share cultural and linguistic affinities with Tibet (Rizvi, 1996). The main occupation of the Changpa tribal community is animal husbandry.
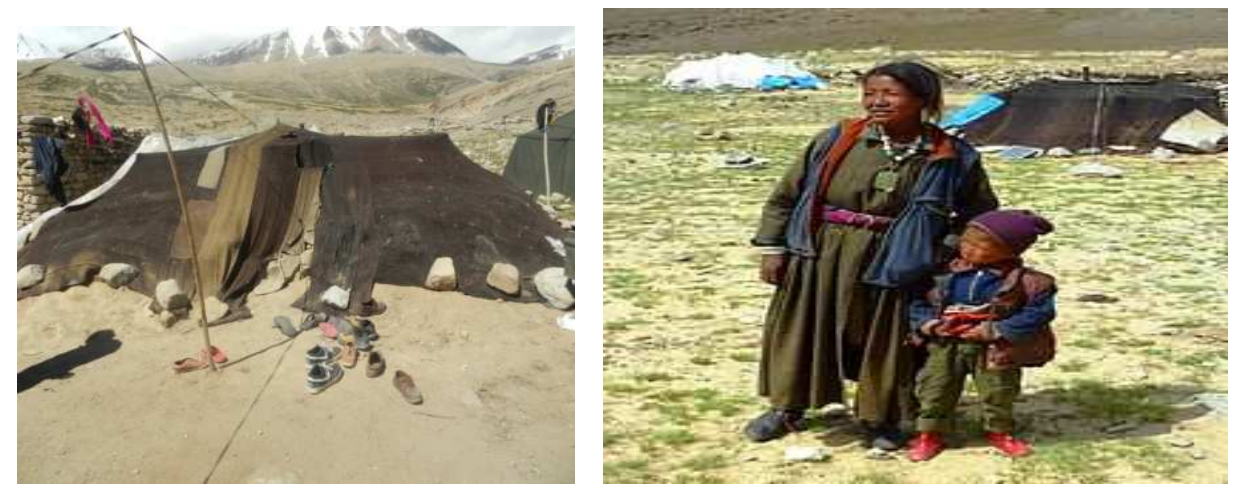

Figure 1: Changpa Wearing a Traditional Dress and Rebo (Tent) of Nomads 
The changpa nomads live in tents which are known as rebos. Rebo is made from yak wool and spun into yarn by the families. The rebo functions as bedroom, dining room and kitchen with a local stove in the centre. The rebo was finished with homemade carpets woven of yak and sheep wool in beautiful colours.

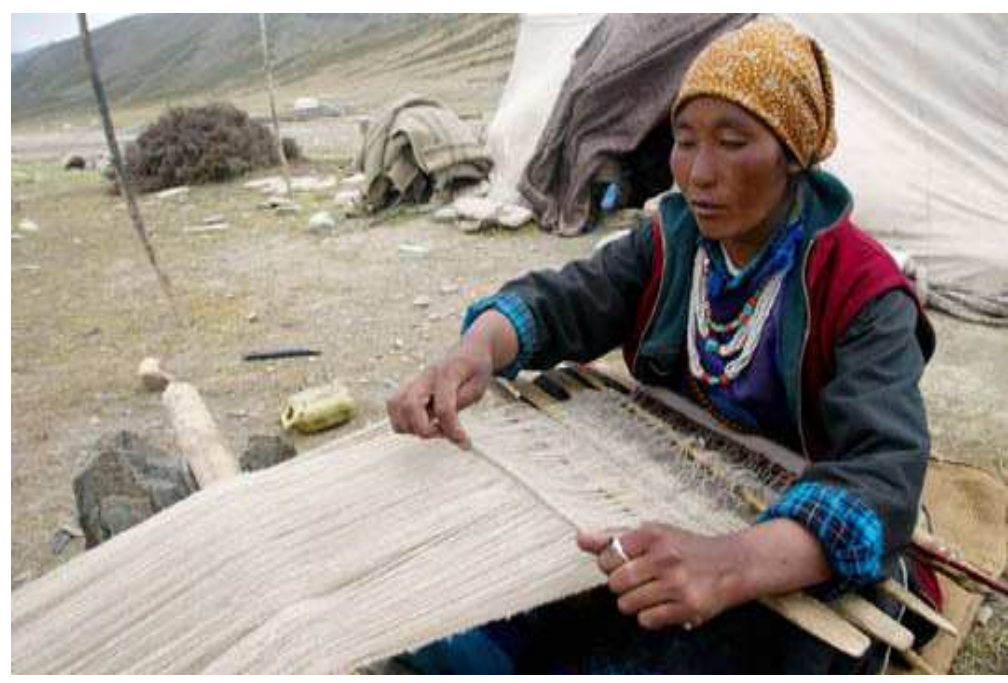

Figure 2: Changthangi Women Weaving Pashmina Shawl

The nomads of the Changthang produce the finest pashmina wool in the world, which is the thin and fine inner wool from the changra goat. Pashmina is also known as cashmere, and the fine quality is due to the harsh climate on the high mountain plateau where the goats are reared.(Goodall, SK 2003), ( Chaudhuri, 2000).

\section{LITERATURE OF THE STUDY}

Stanzin Namgail (2015) conducted a study on "Marriage and Changing Pattern Among the Changpa Tribe of Ladakh. The finding of the study attempt to understand the social relationships involved in the marriage of changpa tribe of ladakh with a specific focus on rules, norms and patterns that govern the construction of social relationship in the marriage system.

Naess, (2003) Found that according to the changpa nomads, natural hazards and diseases have a much larger impact on the households nowadays than in the past. In the past when e.g. a herder had 400 sheep and goats, he could easily recover after a loss of 20 animals. Nowadays, if a family that owns 40 sheep and goats loses 20 animals, they may have difficulty recovering. The loss could lead to starvation for the whole family. "Environmental hazards affect all households equally and it will therefore have greater effect on poor households.

Rawat and Adhikari (2002) Studied that the Changpa economy, wool is the most important animal product. Recently, a change in the livestock composition has been observed. The number of pashmina goats has increased due to direct benefits derived from the sale of the wool whereas number of the yaks has decreased.

Study by the Ahmed, (2000) shows that the nomads had been trading wool, salt and livestock products with agricultural products in other areas. The vehicular traffic caused an abandonment of the old trading routes and the nomads no longer felt that they had to travel the long distances for trading food when the rations now came to them by trucks.

Margolis (2000) found that the famous pashm (cashmere), the oily under wool of goat, was produced by the 
pastoralists on the high altitude plateau of Changthang and western Tibet and it was made into world high quality shawls.

\section{OBJECTIVES OF THE STUDY}

To study the life style of changpa nomads

To study the culture of changpa nomads of Changthang

\section{METHODOLOGY}

The sample for the study was drawn from Nyoma block of Changthang region of Leh district. Nyoma block consists of 18 villages from which 7 villages were selected for the study, namely, Hanley, Koyul, Korzok, Samad, Kharnak, Angkung and Sumdo. From Hanley, Karzok and Samad 40 households were selected and 15 households were selected from Karnak, Ankung and Sumdo and from Koyul 25 households were selected for the study. Which makes total of 190 families (households) in the study area. Both primary and secondary data were used. The primary data was collected through participant observation and a self structured interview schedule method was used for collecting the desired information. The secondary data was collected from the published reports, magazines etc, and from various official sources. Data was analyzed in accordance with the data collection.

\section{RESULT AND DISCUSSIONS}

Table 1: Type of House

\begin{tabular}{|c|c|c|c|c|c|c|c|c|c|c|c|c|c|c|}
\hline \multirow{2}{*}{ House } & \multicolumn{2}{|c|}{ Village1 } & \multicolumn{2}{|c|}{ Village2 } & \multicolumn{2}{|c|}{ Village 3} & \multicolumn{2}{|c|}{ Village4 } & \multicolumn{2}{|c|}{ Village5 } & \multicolumn{2}{|c|}{ Village6 } & \multicolumn{2}{|c|}{ Village7 } \\
\hline & n & $\%$ & n & $\%$ & n & $\%$ & n & $\%$ & $\mathbf{n}$ & $\%$ & n & $\%$ & $\mathrm{n}$ & $\%$ \\
\hline Kaccha(mud h & & & & & & & & & & & & & & \\
\hline Tents (rebo) & 31 & 100 & 58 & 100 & 19 & 100 & 29 & 100 & 23 & 100 & 62 & 100 & 56 & 100 \\
\hline Semi pucca & - & - & - & - & - & - & - & - & - & - & - & - & - & - \\
\hline Pucca & - & - & - & - & - & - & - & - & - & - & - & - & - & - \\
\hline Total & 31 & 100 & 58 & 100 & 19 & 100 & 29 & 100 & 23 & 100 & 62 & 100 & 56 & 100 \\
\hline
\end{tabular}

The data presented in table no.1 reveals that from all the seven villages, $100 \%$ of women respondents (i.e. changpa nomads) were staying in yak wool tents (rebo) which was made from traditionally yak wool. The rebo was very warm. They move several times a year with their rebo and spend their whole life in that portable yak-hair tents (rebo). All the Changpa nomads' rear goats, sheep, yaks, horses and graze their herds on communally regulated allotted pastures land and they keep a dog to protected the herds.

Table 2: Source for Heating Purpose

\begin{tabular}{|c|c|c|c|c|c|c|c|c|c|c|c|c|c|c|}
\hline \multirow{2}{*}{$\begin{array}{c}\text { Source of } \\
\text { Heating Purpose }\end{array}$} & \multicolumn{2}{|c|}{ Village 1} & \multicolumn{2}{|c|}{ Village 2} & \multicolumn{2}{|c|}{ Village 3} & \multicolumn{2}{|c|}{ Village 4} & \multicolumn{2}{|c|}{ Village5 } & \multicolumn{2}{|c|}{ Village6 } & \multicolumn{2}{|c|}{ Village7 } \\
\hline & n & $\%$ & n & $\%$ & n & $\%$ & n & $\%$ & $\mathbf{n}$ & $\%$ & n & $\%$ & n & $\%$ \\
\hline Bukhari & 31 & 100 & 58 & 100 & 19 & 100 & 29 & 100 & 23 & 100 & 62 & 100 & 56 & 100 \\
\hline Heat king & - & - & - & - & - & - & - & - & - & - & - & - & - & - \\
\hline Other & - & - & - & - & - & - & - & - & - & - & - & - & - & - \\
\hline Total & 31 & 100 & 58 & 100 & 19 & 100 & 29 & 100 & 23 & 100 & 62 & 100 & 56 & 100 \\
\hline
\end{tabular}

Table 2 reveals that $100 \%$ of changpa nomads used bukhari for their heating purpose. They used wood and cow dung cake as fuel in bukhari. Bukhari was used for dual purpose i:e cooking and heating the room.

Table 3: Important Traditional Religious Festival and Ceremonies Celebrated

\begin{tabular}{|c|c|c|c|c|c|c|c|}
\hline Traditional & Village1 & Village2 & Village3 & Village4 & Village5 & Village6 & Village7 \\
Festival & 31 & 58 & 19 & 29 & 23 & 62 & 56 \\
\hline
\end{tabular}




\begin{tabular}{|l|l|l|l|l|l|l|l|l|l|l|l|l|l|l|}
\hline & $\mathbf{n}$ & $\mathbf{\%}$ & $\mathbf{n}$ & $\mathbf{\%}$ & $\mathbf{n}$ & $\mathbf{\%}$ & $\mathbf{n}$ & $\mathbf{\%}$ & $\mathbf{n}$ & $\mathbf{\%}$ & $\mathbf{n}$ & $\mathbf{\%}$ & $\mathbf{n}$ & $\mathbf{\%}$ \\
\hline $\begin{array}{l}\text { Losar(new year) } \\
\text { and Dalia lama } \\
\text { birthday }\end{array}$ & 31 & 100 & 58 & 100 & 19 & 100 & 29 & 100 & 23 & 100 & 62 & 100 & 56 & 100 \\
\hline Buddha jayanti & - & - & - & - & - & - & - & - & - & - & - & - & - & - \\
\hline
\end{tabular}

An analysis from the table reflects traditional festival of chanpa nomads. Data from the above table reveals that $100 \%$ of the women respondents were celebrating losar festival. The losar festival marks the beginning of New Year in ladakh /Tibet is considered to be the most important festival of the region. Regarding celebrating of important festivals like Losar (New Year), Dalia Lama's birthday, all the respondents from seven village celebrated these festivals with feast and prayer in gompas(monasteries) people enjoyed a good stage fight between the good and the evil, chanting with blazing fire torches and making way into the crowd, ibex deer dancing, and much more. There were blaring music accompanied with dancing, celebration dinner with relatives and friends and unmitigated joy all around. Every year the date and the location of the festival,losar changes. As per as prayers $6.89 \%$ from second village, 57.89\% third,68.96 fourth,13.04\% fifth, $83.87 \%$ sixth, and $62.5 \%$ from seventh village women respondents prayer daily.15.51\% from second, $31.57 \%$ third,24.13\%fourth,56.52\% fifth,3.22\%sixth,5.35\% seventh village women respondents prayer weekly. From first village all the women respondents pray occasionally. Majority $77.58 \%$ from second village, $10.52 \%$ third, $6.89 \%$ fourth, $30.43 \%$ fifth, $12.90 \% 6^{\text {th }}, 32.14 \%$ from seventh village women respondents pray occasionally because they were busy in their daily schedule work like household chores and taking care livestock.

Table 4: Mostly Commonly Worn Dress

\begin{tabular}{|c|c|c|c|c|c|c|c|c|c|c|c|c|c|c|}
\hline \multirow{2}{*}{$\begin{array}{l}\text { Dress } \\
\text { Wear } \\
\text { Mostly }\end{array}$} & \multicolumn{2}{|c|}{$\begin{array}{c}\text { Village1 } \\
31\end{array}$} & \multicolumn{2}{|c|}{$\begin{array}{c}\text { Village2 } \\
58\end{array}$} & \multicolumn{2}{|c|}{$\begin{array}{c}\text { Village3 } \\
19\end{array}$} & \multicolumn{2}{|c|}{$\begin{array}{c}\text { Village4 } \\
29\end{array}$} & \multicolumn{2}{|c|}{$\begin{array}{c}\text { Village5 } \\
23 \\
\end{array}$} & \multicolumn{2}{|c|}{$\begin{array}{c}\text { Village6 } \\
62 \\
\end{array}$} & \multicolumn{2}{|c|}{$\begin{array}{c}\text { Village7 } \\
56\end{array}$} \\
\hline & $\mathrm{n}$ & $\%$ & $\mathbf{n}$ & $\%$ & $\mathbf{n}$ & $\%$ & n & $\%$ & $n$ & $\%$ & $\mathbf{n}$ & $\%$ & $n$ & $\%$ \\
\hline Ladakhi & 31 & 100 & 58 & 100 & 19 & 100 & 29 & 100 & 23 & 100 & 62 & 100 & 56 & 100 \\
\hline Tibetan & - & - & - & - & - & - & - & - & - & - & - & - & - & - \\
\hline Indian & - & - & - & - & - & - & - & - & - & - & - & - & - & - \\
\hline Total & 31 & 100 & 58 & 100 & 19 & 100 & 29 & 100 & 23 & 100 & 62 & 100 & 56 & 100 \\
\hline
\end{tabular}

Table no 4 illustrated that $100 \%$ of women respondents wear ladakhi traditional dress Gonchas. Changthangi Women weave cloth from wool acquired from Yak, sheep and goats. Gonchas which were worn by people made from coarse homespun woolen cloth and dark shade of maroon or black. Some changpa women also wear another robe known as "Kuntop" with the additional attire, i-e actually a fascinating and colorful shawl and it is called as "Bok". 


\section{CONCLUSIONS}

It is concluded that $100 \%$ of the changpa nomads were staying in tents (rebos) which is made from yak wool.All the changpa women from Changthang were celebrating losar festival. The losar festival marks the beginning of new year in ladakh and is also considered to be the most important festival of the region. Women from the Changthang wear ladakhi traditional dress gonchas. Goncha in black velvet, silver gleam of piping at the border and collar. It has a full skirt with several small pleats which is secured with a belt tied around the waist. The loose trousers are used with Goncha and both the males and the females use this dress with a slight variation. Majority of the respondents prayer occasionally because they are busy in their household chores.

\section{REFERENCES}

1. Ahmed, M. (1997). The salt trade: Rupshu's Annual Trek to Tso Kar. Recent research on Ladakh, vol. 8: 32-48.

2. Chaudhuri, A (2000) Change in Changthang: to stay or to leave? Economic and political weekly, January 8: pp.52-58.

3. Dollfus, P (2013) Mountain deities among the nomadic communities of Kharnak (Eastern Ladakh). In: Van Beek, K Brix Bertelsen, P Pedersen (Eds.):Ladakh: Culture, History and Development between Himalaya and Karakoram.Aarhus, Denmark:Aarhus University Press, pp. 92-118

4. Goodall, SK ( 2003) Rural-to-urban migration and urbanization in Leh, Ladakh: A case of three nomadic pastoral communities. Mountain Research and Development 24: 218-225.

5. Margolis, E. S. (2000). War at the top of the world: the struggle for Afghanistan, Kashmir and Tibet. Routledge, New York.

6. Naess, M. W. (2003). Living with risk and uncertainty: The Case of the Nomadic Pastoralists in the Aru Basin. Ms Thesis. University of Troms $\phi$, Norway

7. Rawat GS, Adhikari BS (2002). Vegetation Structure and Patterns of Livestock Grazing in Tso-Kar Basin, Eastern Ladakh. IRs-Liss with the Help of Global Positioning

8. Rizvi, J. (1996). Ladakh: Crossroads of High Asia. Oxford University Press, New Delhi.

9. Stanzin Namgail (2015) Marriage and Changing pattern among the tribe of ladakh. EPRA international journal of economic 
